\title{
Implementation Of Backpropagation Artificial Network Methods for Early Children's Intelligence Prediction
}

\author{
I Budiman, $A$ Mubarak*, $S$ Kapita, $S$ Do. Abdullah, and $M$ Salmin \\ Informatics Department, Faculty of Engineering, Universitas Khairun, Ternate, Indonesia
}

\begin{abstract}
Intelligence is the ability to process certain types of information derived from human biological and psychological factors. This study aims to implement a Backpropagation artificial neural network for prediction of early childhood intelligence and how to calculate system accuracy on children's intelligence using the backpropagation artificial neural network method. The Backpropagation Neural Network method is one of the best methods in dealing with the problem of recognizing complex patterns. Backpropagation Neural Networks have advantages because the learning is done repeatedly so that it can create a system that is resistant to damage and consistently works well. The application of the Backpropagation Neural Network method is able to predict the intelligence of early childhood. The results of the calculation of the Backpropagation Artificial Neural Network method from 42 children's intelligence data being tested, with 27 training data and 15 test data, the results obtained $100 \%$ accuracy percentage results.
\end{abstract}

Keywords: Artificial Network, Algoritm, Early childhood intelligence

\section{Introduction}

Children are very noble creatures that God has created So parents should treat their children as special as possible. Without any shortcomings, including in the fulfillment of children's social emotional development.

Children aged 0-5 are like white paper without ink, but if they are stained with ink that leads to goodness, the child will become a good person. Vice versa, At this age, children imitate everything they see around them If the child sees the gloomy side of life from a messy family, it is possible that the child will become a bad person. [1] In Indonesia, according to the Central Bureau of Statistics, children under five in 2005 amounted to 20.87 million people, but only about 60 percent of those who can be served with good education such as Playgroups, Playgrounds and others managed by the government and the general public. This means that there are still around $40 \%$ or around 8.35 million children under five who have not been touched by education. [2].

Neural Networks is a powerful data model that is able to capture and represent complex Input-Output relationships, because of its ability to solve several problems, it is relatively easy to use, robust to input data, speed for execution, and initialize complex systems. [3].

\section{Literature review}

\footnotetext{
*Corresponding author: amuba029@unkhair.ac.id
}

\subsection{Artificial Neural Network}

An artificial neural network is one of the artificial representations of the human brain which always tries to simulate the learning process in the human brain. While the nerves themselves are cells that process information in the brain and form a network as a unit that connects the nerves. Artificial terms used in artificial neural networks are implemented using a computer program that is able to complete a number of calculation processes during the learning process. Artificial neural networks model a structure similar to the human brain. [4]

\subsection{Artificial Neural Network Architecture}

Network architecture and training algorithms determine the models of Artificial Neural Networks. The architecture is useful for explaining the direction of travel of the signal or data in the network. While the learning algorithm explains how the connection weights must be changed so that the desired input output pair can be achieved. In each connection weight price changes can be made in various ways, depending on the type of training algorithm used. By adjusting the magnitude of this weight value, it is expected that the network performance in studying various patterns expressed by each input-output pair will increase. [5]. 


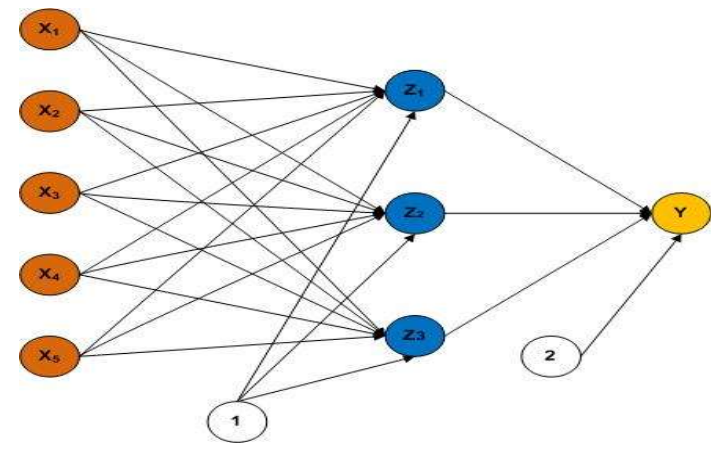

Fig.1. Artificial Neural Network Architecture

\subsection{Early Childhood Intelligence}

Intelligence is the ability to process certain types of information derived from human biological and psychological factors. An intelligence involves the ability to solve problems or design a product that is a consequence of a particular community or cultural setting. The creation of cultural products allows one to capture and convey knowledge or express one's conclusions, beliefs, or feelings. [6]

\subsection{Backpropagation Algoritm}

The steps of the Backpropagation Algorithm are as follows. [13]:

Step 0: Initialize weights $(-0.5)$ to 0.5 ,

Step 1: If the condition is not met, perform steps 2-9.

Step 2: For each training pair, do steps 3-8.

\section{Forward Propagation}

Step 3: Each input unit $\left(\mathrm{x}_{\mathrm{i}}, \mathrm{i}=1,2,3, \ldots, \mathrm{n}\right)$ receive signal $\mathrm{x}_{\mathrm{i}}$

and forward the signal to all units in the layer above it (hidden layer),

Step 4: Each unit on a layer hidden $\left(z_{i}, j=1,2,3, \ldots, p\right)$ summing up the input signals.

$$
\mathrm{z}_{-} \mathrm{in}_{\mathrm{j}}=\mathrm{b} 1_{\mathrm{j}}+\sum_{\mathrm{i}=1}^{\mathrm{N}} \mathrm{X}_{\mathrm{i}} * \mathrm{~V}_{\mathrm{ij}}
$$

Use the activation function to calculate the output signal.

$$
\mathrm{z}_{\mathrm{j}}=\frac{1}{1+\mathrm{e}^{-\mathrm{z}_{-} \mathrm{in}_{\mathrm{j}}}}
$$

Step 5: Each output unit $\left(\mathrm{y}_{\mathrm{k}}, \mathrm{k}=1,2, . . \mathrm{n}\right)$

summing up the input signals.

$$
{\mathrm{y} \_i n_{\mathrm{k}}}=\mathrm{b} 2_{\mathrm{k}}+\sum_{\mathrm{i}=1}^{\mathrm{P}} \mathrm{Z}_{\mathrm{i}} * \mathrm{~W}_{\mathrm{jk}}
$$

Use the activation function to calculate the output signal,

$$
\mathrm{z}_{\mathrm{j}}=\frac{1}{1+\mathrm{e}^{-\mathrm{z}-\mathrm{in}_{\mathrm{j}}}}
$$

And send the signal to all the upper layer units (output units).
Note: Step (3) is performed as many as the number of hidden layers.

\section{Reverse Propagation}

Step 6: Each output unit $\left(\mathrm{y}_{\mathrm{k}}, \mathrm{k}=1,2, \ldots, \mathrm{m}\right)$ receives the target pattern corresponding to the learning input pattern, calculates the error gradient in the output layer

$$
\begin{aligned}
& \mathrm{E}_{\mathrm{k}}=\left(\mathrm{t}_{\mathrm{k}}-\mathrm{y}_{\mathrm{k}}\right) \\
& \delta_{\mathrm{k}}=\mathrm{y}_{\mathrm{k}} *\left(1-\mathrm{y}_{\mathrm{k}}\right) * \mathrm{E}_{\mathrm{k}}
\end{aligned}
$$

Then calculate the weight correction (which will later be used to obtain the value of $\mathrm{w}_{\mathrm{jk}}$ )

$$
\Delta \mathrm{w}_{\mathrm{jk}}=\alpha * \delta_{\mathrm{k}} * \mathrm{z}_{\mathrm{j}}
$$

Also calculate the bias correction (which will later be used to correct the value of $\mathrm{b} 2 \mathrm{k}$ )

$$
\Delta \mathrm{b} 2_{\mathrm{k}}=\alpha * \delta_{\mathrm{k}}
$$

Step (6) is also performed as many as the number of hidden layers.

Step 7: Calculate the error gradient for the neurons in the hidden layer.

$$
\delta 1_{\mathrm{j}}=\mathrm{z}_{\mathrm{j}} *\left[1-\mathrm{z}_{\mathrm{j}}\right] * \sum_{\mathrm{k}=1}^{1} \delta_{\mathrm{k}} * \mathrm{w}_{\mathrm{jk}}
$$

Then calculate the weight correction (which will later be used to correct the value of $v_{i j}$ ), Also calculate the bias correction (which will later be used to correct the value of $\mathrm{b} 1_{\mathrm{j}}$ ).

$$
\Delta \mathrm{b} 1_{\mathrm{j}}=\alpha \delta 1_{\mathrm{j}}
$$

Step 8 : Each output unit $\left(\mathrm{y}_{\mathrm{k}}, \mathrm{k}=1,2, ., \mathrm{n}\right)$

Fix the bias and weight $(\mathrm{j}=0,1,2, \ldots, \mathrm{p})$

$$
\begin{gathered}
\mathrm{w}_{\mathrm{jk}}(\text { baru })=\mathrm{w}_{\mathrm{jk}}(\text { lama })+\Delta \mathrm{w}_{\mathrm{jk}} \\
\mathrm{b} 2_{\mathrm{k}}(\text { baru })=\mathrm{b} 2_{\mathrm{k}}(\text { lama })+\Delta \mathrm{b} 2_{\mathrm{k}}
\end{gathered}
$$

Each hidden unit $\left(z_{j}, j=1,2,3, \ldots, p\right)$

Fix the bias and weight $(\mathrm{i}=0,1,2, \ldots, \mathrm{n})$

$$
\begin{aligned}
\mathrm{v}_{\mathrm{ij}}(\text { baru }) & =\mathrm{v}_{\mathrm{ij}}(\text { lama })+\Delta \mathrm{v}_{\mathrm{ij}} \\
\mathrm{b} 1_{\mathrm{j}}(\text { baru }) & =\mathrm{b} 1_{\mathrm{j}}(\text { lama })+\Delta \mathrm{b} 1_{\mathrm{j}}
\end{aligned}
$$

Step 9: Calculate MSE (Mean Square Error)

$$
\operatorname{MSE}=\frac{1}{\mathrm{~N}} \operatorname{sum}\left(\mathrm{E}_{\mathrm{k}}^{2}\right)
$$

\section{Results and Discussion}

\subsection{Analysis Method}

In this section, we will analyze the backpropagation method to find the level of accuracy of the method in predicting or classifying test data categories. The data that will be used in the analysis method is 15 data. From the results obtained between teacher assessments and system calculations, it can be concluded that teacher assessments and systems have a suitable similarity. From the table of results above can be accuracy.

$$
\begin{aligned}
\text { accuracy } & =\frac{\mathrm{TP}+\mathrm{TN}}{\mathrm{TP}+\mathrm{TN}+\mathrm{FP}+\mathrm{FN}} \\
& =\frac{11+4}{11+4+0+0}=\frac{15}{15} * 100=100 \%
\end{aligned}
$$




\subsection{Analysis Of Test Results}

After carrying out various combinations of learning with the same initial weight, target error, and maximum iteration, it turns out that the percentage results are different. Table 1 shows the test results with several learning rates.

Table 1. Training results with a combination of learner levels

\begin{tabular}{|c|c|c|c|c|}
\hline \multirow{2}{*}{$\begin{array}{l}\mathbf{N} \\
\mathbf{0}\end{array}$} & \multirow{2}{*}{$\begin{array}{l}\text { Learning } \\
\text { Rate }\end{array}$} & \multirow{2}{*}{ MSE } & \multirow{2}{*}{ Iteration } & Result (\%) \\
\hline & & & & Accuracy \\
\hline 1 & 0,0001 & $\begin{array}{c}0,20658531863 \\
441\end{array}$ & 10000 & $73,333 \%$ \\
\hline 2 & 0,001 & $\begin{array}{c}0,15087422338 \\
92\end{array}$ & 10000 & $73,333 \%$ \\
\hline 3 & 0,01 & $\begin{array}{c}0,09995733158 \\
7885\end{array}$ & 10000 & $100 \%$ \\
\hline 4 & 0,1 & $\begin{array}{c}0,00611297024 \\
7\end{array}$ & 10000 & $100 \%$ \\
\hline 5 & 0,2 & $\begin{array}{c}0,09765114872 \\
3925\end{array}$ & 10000 & $100 \%$ \\
\hline 6 & 0,3 & $\begin{array}{c}0,09864220917 \\
9482 \\
\end{array}$ & 10000 & $100 \%$ \\
\hline 7 & 0,4 & $\begin{array}{c}0,09675878126 \\
9242\end{array}$ & 10000 & $100 \%$ \\
\hline 8 & 0,5 & $\begin{array}{c}0,09785553397 \\
0041\end{array}$ & 10000 & $100 \%$ \\
\hline 9 & 0,6 & $\begin{array}{c}0,09316311965 \\
3283 \\
\end{array}$ & 10000 & $100 \%$ \\
\hline 10 & 0,7 & $\begin{array}{c}0,09005702336 \\
2138\end{array}$ & 10000 & $100 \%$ \\
\hline
\end{tabular}

Description: Target error $=0.1$ and Maximum Iteration $=$ 10000 .

From the results of testing the application system with a backpropagation model of 5 input layers, 3 hidden layers and 1 output layer that has been made with different learning rate values, it has succeeded in getting the highest percentage of accuracy, which is $100 \%$ and is included in the Excellent Classification accuracy category. And the lowest accuracy result is $73.333 \%$ and is included in the Fair Classification category.

\subsection{Interface Implementation}

\section{Home}

This page aims to welcome the user when successfully accessing the application.

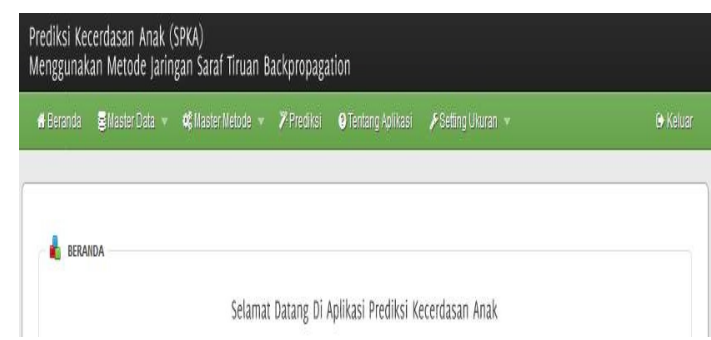

Fig.2. Main Page

\section{Backpropagation Model Page}

The backpropagation page presents a list of backpropagation method models. This study uses 5 inputs, 3 hidden, 1 output.

Model Backproparation

\begin{tabular}{|c|c|c|c|c|c|}
\hline \multicolumn{6}{|c|}{ 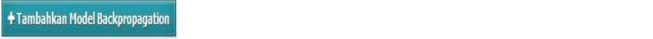 } \\
\hline Inputlayer & Hidden Layer & Ouppit Lajer & Status & Aksi & \\
\hline 45 & 3 & 1 & Tidiak kakif & Inisilisiabobt & Ahpors \\
\hline 45 & 3 & 1 & Tinak Akifif & Q nnisalsai iobot & thapus \\
\hline$\forall 5$ & 3 & 1 & Tidak Akifi" & Q nisialisaibobot & thapis \\
\hline 05 & 3 & 1 & Altif & Cinsisalka ibbot & Athaps \\
\hline
\end{tabular}

Fig.3. Backpropagatin Model Page

\section{Data Testing Page}

The test page aims to test the test data which consists of 15 data consisting of 11 intelligent data and 4 unintelligent data.

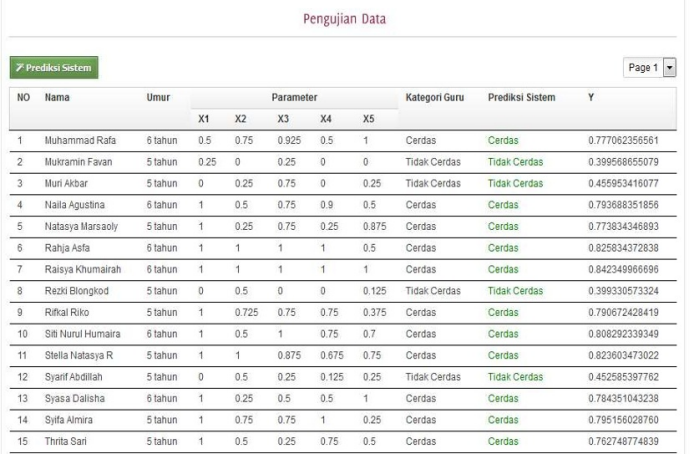

Fig.4. Data Testing Page

After doing the test, you will get the results of system accuracy in classifying the data. In the test, a graph of the test results will also be obtained.

Hasil Analisi

\begin{tabular}{llll}
\hline & Jumlah Data & Hasil Klasifikasi & Persentase(\%) \\
\hline Siswa Cerdas & 11 & 11 & $100 \%$ \\
\hline Siswa Tidak Cerdas & 4 & 4 & $100 \%$ \\
\hline Total & $\mathbf{1 5}$ & $\mathbf{1 5}$ & $\mathbf{1 0 0 \%}$ \\
\hline
\end{tabular}

Fig.5. Accuracy

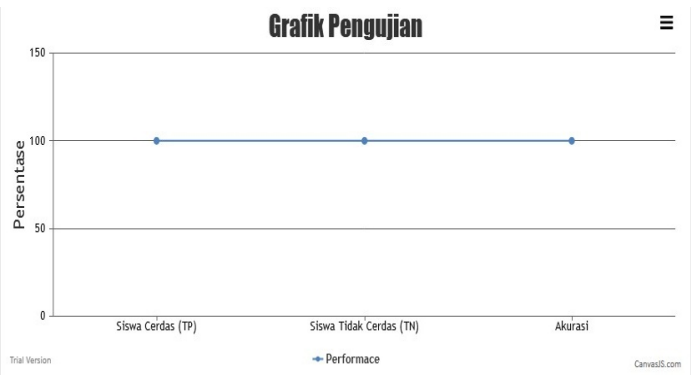

Fig. 6. Test Results Graph 


\section{Conclusion}

Training data learning (data training) in order to obtain weights that will be used for testing, then testing data using weights derived from the training process. The criteria used in determining the prediction of children's intelligence include verbal development, emotional development, social development, gross and fine motor neurodevelopment, and cognitive development. From 10 learning rate experiments to find the average accuracy, the accuracy results obtained are $100 \%$ as the excellent classification category, and the implementation of the backpropagation method of artificial neural networks can be carried out on early childhood intelligence data.

\section{References}

1. Muliana, Anizar Ahmad, Y. (2017). Perkembangan Perilaku Anak Dari Keluarga Yang Bercerai Di Kecamatan Ulim Kabupaten Pidie Jaya, 23(39870423), 946-952.

2. Siswina, Shahib, M. N., \& Rasyad, A. S. (2016). Pengaruh Stimulasi Pendidikan Terhadap Perkembangan Kecerdasan Anak Usia 3-6 Tahun. Jurnal Ilmiah Bidan, 1(2), 27-33.

3. Sudarsono, A. (2016). Jaringan Syaraf Tiruan Untuk Memprediksi Laju Pertumbuhan Penduduk Menggunakan Metode. Media Infotama, 12(1), 6169.

4. Hendri. (2014). Character Recognition Dengan Menggunakan Jaringan Syaraf Tiruan, III(2), 1-5.

5. Purnamasari, R. W. (2013). Implementasi Jaringan Syaraf Tiruan Backpropagation Sebagai Sistem Deteksi Penyakit Tuberculosis (TBC), 1-130.

6. Masdudi. (2017). Konsep pembelajaran multiple intelligences bagi anak usia dini, Vol 3(1), 1-27.

7. Vandansari. (2015). Perbedaan perkembangan verbal antara anak usia 3-5 tahun yang diasuh orang tua sendiri dengan anak usia 3-5 tahun yang diasuh di tempat penitipan anak. Biomass Chem Eng, 49(23-6).

8. Filtri, H. (2017). Perkembangan Emosional Anak Usia Dini Usia 5-6 tahun Ditinjau dari Ibu yang Bekerja. PAUD Lectura: Jurnal Pendidikan Anak Usia Dini, 1(1), 32-37.

9. Mayar, F. (2014). Perkembangan Sosial Anak Usia Dini Sebagai Bibit Untukmasa Depan Bangsa FaridaMayar. AL-Ta Lim, 20(3), 459-464.

10. Saputra, wahyu nanda eka, \& Setianingrum, I. (2016). Perkembangan motorik halus anak usia 3-4 tahun di kelompok bermain cendekia kids school madiun dan implikasinya pada layanan konseling. Jurnal Care, 03(2016), 1-11. Retrieved from https://scholar.google.co.id/scholar?hl=id\&as_sdt=0 $\% 2 \mathrm{C} 5 \& \mathrm{q}=$ Prayitno + dan + Erman + Amti + adalah + pro ses + pemberian+bantuan+yang + dilakukan + melalui + wawancara + konselingoleh + seorang + ahli\&btnG $=$

11. Annisa Rachmadyana. (2017). Pengembangan motorik kasar anak usia dini melalui kegiatan senam irama pada kelompok a di ra masyitoh 7 kota magelang. Universitas islam negeri sunan kalijaga yogyakarta, 01, 1-7. Retrieved from http://www.albayan.ae

12. Sitti Aisyah Mu'min. (2013). Teori Perkembangan Kognitif Jean Piagat, 6(1), 89-99.

13. S Kusumadewi. (2004). Membangun Jaringan Syaraf Tiruan Menggunakan Matlab dan Excel Link. Yogyakarta : Graha Ilmu. 